Article

\title{
Equation of State for Natural Almandine, Spessartine, Pyrope Garnet: Implications for Quartz-In-Garnet Elastic Geobarometry
}

\author{
Suzanne R. Mulligan $1,2, * \mathbb{D}$, Elissaios Stavrou ${ }^{1,3,4}{ }^{\oplus}$, Stella Chariton ${ }^{5}$, Oliver Tschauner ${ }^{2}$, Ashkan Salamat ${ }^{6}$, \\ Michael L. Wells ${ }^{2}$, Alexander G. Smith ${ }^{6}$, Thomas D. Hoisch ${ }^{7}$ and Vitali Prakapenka ${ }^{5}$
}

1 Lawrence Livermore National Laboratory, Physical and Life Sciences Directorate, Livermore, CA 94550, USA; elissaios.stavrou@gtiit.edu.cn

2 Department of Geoscience, University of Nevada, Las Vegas, NV 89134, USA; oliver.tschauner@unlv.edu (O.T.); michael.wells@unlv.edu (M.L.W.)

3 Materials and Engineering Science Program, Guangdong Technion-Israel Institute of Technology, 241 Daxue Road, Jinping District, Shantou 515063, China

4 Department of Materials Science and Engineering, Technion-Israel Institute of Technology, Haifa 32000, Israel

5 Center for Advanced Radiation Sources, University of Chicago, Chicago, IL 60637, USA;

chariton@cars.uchicago.edu (S.C.); prakapenka@cars.uchicago.edu (V.P.)

6 Department of Physics and Astronomy, University of Nevada Las Vegas, Las Vegas, NV 89134, USA; ashkan.salamat@unlv.edu (A.S.); smith613@unlv.nevada.edu (A.G.S.)

7 School of Earth \& Sustainability, Northern Arizona University, Flagstaff, AZ 86011, USA; Thomas.Hoisch@nau.edu

check for updates

Citation: Mulligan, S.R.; Stavrou, E.; Chariton, S.; Tschauner, O.; Salamat, A.; Wells, M.L.; Smith, A.G.; Hoisch, T.D.; Prakapenka, V. Equation of State for Natural Almandine, Spessartine, Pyrope Garnet: Implications for Quartz-In-Garnet Elastic Geobarometry. Minerals 2021, 11, 458. https://doi.org/10.3390/ $\min 11050458$

Academic Editor: Julien Siebert

Received: 16 March 2021

Accepted: 22 April 2021

Published: 27 April 2021

Publisher's Note: MDPI stays neutral with regard to jurisdictional claims in published maps and institutional affiliations.

Copyright: (c) 2021 by the authors. Licensee MDPI, Basel, Switzerland. This article is an open access article distributed under the terms and conditions of the Creative Commons Attribution (CC BY) license (https:// creativecommons.org/licenses/by/ $4.0 /)$.
* Correspondence: mullis1@unlv.nevada.edu
Abstract: The equation of state (EoS) of a natural almandine ${ }_{74}$ spessartine $_{13}$ pyrope $_{10}$ grossular $_{3}$ garnet of a typical composition found in metamorphic rocks in Earth's crust was obtained using single crystal synchrotron X-ray diffraction under isothermal room temperature compression. A third-order Birch-Murnaghan EoS was fitted to P-V data and the results are compared with published EoS for iron, manganese, magnesium, and calcium garnet compositional end-members. This comparison reveals that ideal solid solution mixing can reproduce the EoS for this intermediate composition of garnet. Additionally, this new EoS was used to calculate geobarometry on a garnet sample from the same rock, which was collected from the Albion Mountains of southern Idaho. Quartz-ingarnet elastic geobarometry was used to calculate pressures of quartz inclusion entrapment using alternative methods of garnet mixing and both the hydrostatic and Grüneisen tensor approaches. QuiG barometry pressures overlap within uncertainty when calculated using EoS for pure endmember almandine, the weighted averages of end-member EoS, and the EoS presented in this study. Grüneisen tensors produce apparent higher pressures relative to the hydrostatic method, but with large uncertainties.

Keywords: garnet; equation of state; solid solution; host inclusion elastic geobarometry; QuiG

\section{Introduction}

Garnets are a family of mineral structures with the formula $\mathrm{X}_{3} \mathrm{Y}_{2}\left[\mathrm{ZO}_{4}\right]_{3}$. Most silicate garnets have cubic symmetry forming dodecahedral crystals in the space group Ia3d with an 8-coordinated X-site, 6-coordinated Y-site, and 4-coordinated Z-site [1]. The most common garnets contain corner sharing $\mathrm{YO}_{6}$ octahedra and $\mathrm{ZO}_{4}$ tetrahedra with $\mathrm{X}$ cations contained within this three-dimensional framework. Substitution of different cations into the X-site defines common compositional end-members of the garnet group in metamorphic rocks [2]. Garnets in the mantle commonly exhibit different substitution mechanisms [3], which are not addressed here. This study is restricted to crustal aluminosilicate garnets $(\mathrm{Z}=\mathrm{Si} ; \mathrm{Y}=\mathrm{Al})$, that are common metamorphic and igneous minerals in the Earth's crust. These garnets are dominated by the compositional end-members pyrope $\left(\mathrm{Mg}_{3} \mathrm{Al}_{2}\left[\mathrm{SiO}_{4}\right]_{3}\right)$, almandine 
$\left(\mathrm{Fe}_{3} \mathrm{Al}_{2}\left[\mathrm{SiO}_{4}\right]_{3}\right)$, spessartine $\left(\mathrm{Mn}_{3} \mathrm{Al}_{2}\left[\mathrm{SiO}_{4}\right]_{3}\right)$, and grossular $\left(\mathrm{Ca}_{3} \mathrm{Al}_{2}\left[\mathrm{SiO}_{4}\right]_{3}\right)$. They form in a variety of rock types and participate in key metamorphic reactions allowing them to be used to model geologic pressures and temperatures, important for understanding mountain building processes, tectonic histories, and metamorphic reactions. To use garnet in pressure-temperature $(\mathrm{P}-\mathrm{T})$ modeling, the influence of these different $\mathrm{X}$-site cations must be accounted for, and the accuracy of P-T predictions rely on the accuracy of the EoS and thermodynamic mixing models for garnet solid solutions. Despite the importance of garnet and extensive efforts, different mixing models are not universally consistent in how well they reproduce garnet volumes [4]. Furthermore, discrepancies between garnet solid solution mixing volumes derived from calorimetry are often inconsistent with results from X-ray diffraction depending on the EoS model used [5-9].

Because of its abundance in Earth's crust, garnet has been a common focus of crystallographic studies. The almandine $[\mathrm{Fe}]$, spessartine $[\mathrm{Mn}]$, pyrope $[\mathrm{Mg}]$, and grossular $[\mathrm{Ca}]$ end-members have been extensively studied [10-14]. However, in nature, garnet almost never forms as pure end-members, thus end-member garnet volumes at zero pressure $\left(V_{0}\right)$ and bulk moduli $\left(B_{0}\right)$ have to be mixed to account for intermediate compositions. Many models have been proposed for how to mix the thermodynamic properties of garnet solid solutions, but they do not all agree $[4,6,15,16]$. Early experimental work suggested that $\mathrm{Fe}$ and $\mathrm{Mn}, \mathrm{Ca}$ and $\mathrm{Fe}$, and $\mathrm{Ca}$ and $\mathrm{Mn}$ end-member $V_{0}$ and $B_{0}$ mix ideally or nearly-ideally, from which simple mixing models were developed $[5,6]$. However, these models do not fit experimental data from other studies and show poor agreement with other models [7,15]. Ideal mixing was also observed more recently in pyrope-almandine solid solutions with added Mn content in almandine increasing the pressure derivative of the bulk modulus $\left(B_{0}{ }^{\prime}\right)$ following an ideal mixing model [2]. In addition to [2], ideal mixing of garnet endmembers was also demonstrated by $[13,17,18]$. However, for grossular-spessartine solid solutions, non-ideal mixing of of $V_{0}$ and $B_{0}$ is observed $[6,8,9,19]$. The positive ideal mixing of almandine-pyrope solid solutions and the non-ideal mixing behavior of almandinegrossular solid solutions arise from the different sizes of the cations that can occupy the dodecahadral site in garnet, with ionic radii of $0.92 \AA$ for $\mathrm{Fe}^{2+}, 0.89 \AA$ for $\mathrm{Mg}^{2+}$, and $1.12 \AA$ for $\mathrm{Ca}^{2+}$ [8]. Thus, with an ionic radius of $0.96 \AA$ for $\mathrm{Mn}^{2+}$, almandine-spessartine solid solutions are expected to behave similarly to almandine-pyrope. However, deviations from ideal mixing have been found [20]. Non-ideal behavior has been recognized in Fe and $\mathrm{Mg}$ mixing, Fe and Ca mixing, and Fe and Mn mixing [15,16,20-22]. Single crystal studies on the influence of substitution of the $\mathrm{Mg}, \mathrm{Mn}$, and Ca cations together in natural almandine garnets have not been extensively studied. Accurate solid solution models describing the mixing of garnet end-members are crucial for the use of garnet as a geobarometer, and discrepancies between different mixing models have important implications for the accuracy of geobarometers, which are discussed in detail below.

The EoS plays an important role in inclusion-host elastic geobarometery, as entrapment pressures are modeled using the EoS of the host and inclusion minerals [23]. Currently, there is debate within the geologic community about which methods of geobarometrythermodynamic equilibrium geobarometry or elastic geobarometry-more accurately reproduce metamorphic pressures. In light of new advances to the recently developed quartz-in-garnet elastic geobarometer (QuiG), which sometimes yields pressures that are inconsistent with chemical equilibrium-based approaches, there has been increased scrutiny of methods of geobarometry [24-27]. Studies comparing QuiG and thermodynamic equilibrium-based barometers in Barrovian rocks show pressure differences of 0.2 or more GPa calculated by these methods $[26,28,29]$. A possible cause for this discrepancy could be equilibrium thermodynamic approaches involving garnet underestimating pressures of metamorphism due to overstepping of garnet-producing reactions [26,28]. Alternatively, deviation could arise from unrecognized aspect(s) of QuiG causing pressures to be overestimated. There is not a clear consensus on how to calculate final QuiG entrapment pressures since garnet end-member EoS return different pressures and natural garnets are composed of intermediate compositions. One approach is to use only the 
EoS for almandine since most metamorphic garnets used in P-T modeling are closest in composition to this Fe end-member. Another approach is to use a weighted average of the pressures returned for each end-member, weighing the pressures based on the chemical composition of the garnet. Alternatively, a single representative EoS with a composition common to metamorphic garnet can be used if such an EoS is available. Whether or not these alternatives can significantly influence the pressures returned by QuiG has not been thoroughly evaluated. In addition to the bulk moduli, another potential source for error are the thermal expansion coefficients. Differences in the thermal parameters could reveal differences in the calculated entrapment pressures, as thermal expansion has been found to cause significant differences in the compressibilities and mixing behavior of garnet solid solutions [14]. In this study, the simple case is examined to test the bulk moduli effect on EoS mixing and entrapment pressure calculations. Future work will evaluate the effect of the thermal parameters.

Another outstanding question about QuiG geobarometry is the reliability of the hydrostatic calibration for QuiG. Typically, QuiG was calculated assuming hydrostatic compression within quartz, and inclusion pressures were derived from experimentally calibrated Raman band shifts [27,30]. Recently, an alternative approach was developed that uses phonon-mode Grüneisen tensors to calculate strain on each crystallographic axis, and inclusion pressures are obtained from strains [24,31,32]. To the authors' knowledge, no significant deviation has been recognized between these two methods below 3.0 GPa [23,31], and many continue to apply it. To compare these methods, pressures are calculated using both approaches.

Here we report an EoS for a natural garnet of composition $\mathrm{Alm}_{74} \mathrm{Sps}_{13} \operatorname{Prp}_{10} \mathrm{Grs}_{3}$ under compression up to $10.6 \mathrm{GPa}$. The specimen was collected from a middle amphibolite facies pelitic schist from the Albion Mountains of southern Idaho [33]. Garnet from this sample was chosen because the composition is similar to garnets from pelitic schists in other regional metamorphic environments, which represents a common variety of garnet used in P-T modeling. Determination of an EoS for garnet of a common and naturally occurring composition can contribute to our understanding of garnet solid solution mixing and compression in metamorphic rocks, with implications for methods in petrology. In particular, we examine the compressibility of this garnet to understand the effect of $\mathrm{Mn}$, $\mathrm{Mg}$, and Ca on the almandine EoS. The $300 \mathrm{~K}$ (room temperature) isotherm for this natural garnet is obtained by fitting single crystal synchrotron X-ray diffraction (SXD) data collected using a diamond anvil cell (DAC). We compare the newly derived EoS to published EoS on garnet end-members. Additionally, quartz inclusions from a garnet in the same rock sample are analyzed using Raman spectroscopy for QuiG, applying both the Grüneisen tensor and hydrostatic approaches. To test the influence of the garnet EoS on calculated QuiG pressures and to test whether using ideal mixing of the end-member EoS and/or a pure end-member EoS (e.g., almandine) for QuiG is a satisfactory approximation in calculating metamorphic pressures, we calculated entrapment pressures using the the EoS for this natural garnet, the EoS for four end-member garnets, and a weighted average of pressures returned by the end-member EoS that is weighted based on the garnet composition.

\section{Materials and Methods}

A single crystal specimen of natural garnet was used for SXD. A 250-micron sample chamber hole was laser drilled into a steel gasket that was preindented to 65-microns. The specimen was loaded into a BX-90 DAC [34]. The garnet was compressed incrementally in 12 steps up to $10.6 \mathrm{GPa}$. A 4:1 methanol-ethanol mixture was chosen for the pressure transmitting medium as it remains quasi-hydrostatic over that measured pressure range [35]. Ruby and gold flakes were loaded to determine pressure through ruby luminescence [36] and gold EoS [37], respectively.

SXD data were collected at the undulator X-ray diffraction beamline at GeoSoilEnviroCARS (GSECARS) sector13 of the Advanced Photon Source of the Argonne National Laboratory. A Pilatus $1 \mathrm{M} \mathrm{CdTe}$ detector was used to collect pressure dependent SXD. 
The X-ray probing beam spot size was focused to approximately $2-4 \mu \mathrm{m}$; additional details on the experimental setup are in [38].

SXD patterns were indexed and unit cells obtained in CrysAlis [39]. Between 373 and 469 reflections were used for indexation with $R_{\text {int }}=0.015$ to 0.057 . A third-order BirchMurnaghan EoS [40] was fitted to the data using EoSFit7c [41]. This type of equation was chosen to be consistent with previously published end-member EoS $[10,13,14]$ :

$$
P(V)=\frac{3 B_{0}}{2}\left[\left(\frac{V_{0}}{V}\right)^{\frac{7}{3}}-\left(\frac{V_{0}}{V}\right)^{\frac{5}{3}}\right)\left(1+\frac{3}{4}\left(B_{0}^{\prime}-4\right)\left[\left(\frac{V_{0}}{V}\right)^{2 / 3}-1\right]\right)
$$

where $P$ is pressure in GPa, $V_{0}$ is the volume at zero pressure, $V$ is the volume at $P, B_{0}$ is the bulk modulus at zero pressure in $\mathrm{GPa}$, and $B_{0}^{\prime}$ is the pressure derivative of the bulk modulus at zero pressure [40]. $V_{0}, B_{0}, B_{0}^{\prime}$ were left as floating parameters during fitting. The reduced chi-squared value of the fitted EoS (Table 1) was 5.26.

$V_{0}$, obtained from fitting, is compared to $V_{0}$-ideal, which is calculated assuming ideal mixing of the end-members pyrope [14], almandine [14], spessartine [13], and grossular [42] (Table 2). Details on the mixing models are described in the results below. Measured end-member contributions are weighted using garnet chemical data from electron probe micro-analysis (EPMA). $V_{0}$-ideal was calculated using volumes from the published EoS files downloaded from rossangel.com [10,14] for almandine, pyrope, and grossular and [13] for spessartine. $V_{0}$ was unable to be measured for this study, as the sample was damaged during retrieval, therefore post-experiment $V_{0}$ was not collected. Pre-experiment $V_{0}$ was also not measured, as pandemic related restrictions required the sample to be loaded, slightly compressed, and shipped to the beamline for data collection. We recognize the limitations of using only a calculated $V_{0}$, but the consistency of the fitted $V_{0}$ to those of published end-members supports correct determination of the volume.

To obtain garnet and matrix mineral compositions, EPMA chemical analyses were conducted using a Cameca MBX electron microprobe at Northern Arizona University. For garnet, 66 points from rim to rim in the garnet were collected using a spot size of 1-micron and a beam current of 20-27 nA. Garnet zoning profiles were smooth and show a steep spessartine decrease at the rims. Raman data and samples extracted for DAC compression were selected from the interiors of the garnets to avoid sampling the rim. Matrix minerals were analyzed using a voltage of $15 \mathrm{kV}$, beam current of $10 \mathrm{nA}$, and spot diameter of 5-microns. In all analyses, X-rays were accumulated until either the counting time was reached or the standard deviation was less that 0.5 percent. Natural and synthetic standards were used for calibration.

\section{Elastic Geobarometry}

Raman spectra were collected for nine quartz inclusions entrapped within one garnet, which was extracted from the same rock sample as the garnet used to create the EoS in this study. Unoriented Raman Spectroscopy was conducted at UNLV using a Princeton TriVista SP750 in a single spectrometer setup with a Princeton PIXIS 400p CCD detector with 20 micron $x$ micron chip (Acton, Ma, USA ) equipped with a $532 \mathrm{~nm}$ laser, an Optigrate volume Bragg grating super notch filter, and an $1800 \mathrm{gr} / \mathrm{mm}$ diffraction grating using a $\mathrm{NA}=0.42$ objective and a 100-micron spatial filter. Spectra were collected for $35 \mathrm{~s}$ and 5 accumulations at $6 \mathrm{~mW}$ laser power. Large exposed, unstressed matrix quartz in the sample was used as a standard. The average of the quartz standards(QZ) is $465.1278 \mathrm{~cm}^{-1}$ (Table S1). Raman data were fitted in FitYK [43]. Analytical uncertainty is estimated using the standard deviations from QZ (Table S1). The $464 \mathrm{~cm}^{-1}$ band had a standard deviation of $0.1 \mathrm{~cm}^{-1}$, which produces an entrapment pressure uncertainty of $0.05 \mathrm{GPa}$. This uncertainty has been confirmed with Herkimer quartz on this Raman system. The uncertainty on the $207 \mathrm{~cm}^{-1}$ band was significantly higher at $0.3 \mathrm{~cm}^{-1}$. Inclusion pressure uncertainties reported by EntraPT [44] are 0.201 GPa, producing an entrapment pressure uncertainty of $0.276 \mathrm{GPa}$ at $559{ }^{\circ} \mathrm{C}$. Inclusion pressures that are referred to as ' $\mathrm{P}_{\text {stress }}$ ' were calculated using Grüneisen tensors in EntraPT [44]. These are calculated using only two modes following [45], rather than the preferred three, as the $128 \mathrm{~cm}^{-1}$ mode was not used due to 
noise from the incident laser line causing a high signal-to-noise ratio and high background at the 128 position, which significantly increased the fit uncertainty on this mode. Only four inclusions were suitable for calculating pressures using three modes, these data are provided in the supplement (Table S2). Because anisotropy primarily affects the inclusion pressure, not entrapment pressure, the use of two modes is sufficient here, as the Raman data are included only to test for possible changes to the pressures returned by QuiG with changing EoS, and precise pressures of metamorphism are not required for this comparison. Inclusion pressures referred to as ' $\mathrm{P}_{464}$ ' were calculated assuming hydrostatic compression and using the calibration for the $464 \mathrm{~cm}^{-1}$ mode shift [30]. Entrapment pressures are calculated using EoSFit7- $\mathrm{P}_{\text {inc }}$ [25]. EntraPT [44] reports entrapment pressures, but these were not used, as EoS cannot be input into the software, and only almandine, grossular, and pyrope EoS are available to use. In EoSFit7-P $\mathrm{P}_{\text {inc }}$, EoS can be uploaded. The following mineral EoS were used to calculate entrapment pressures for this study: quartz (full curved) [46]; almandine [14], pyrope [14], grossular $B_{0}^{\prime}[10]$, and spessartine from Thermocalc database tc-ds62 [47] with a shear modulus $\left(G_{0}\right)$ of 96 [42]. The EoS used to calculate the entrapment pressure for end-member spessartine was taken from Thermocalc rather than the published EoS [13] because the latter does not incorporate $G_{0}$, and thus it is incompatible with EoSFit7- $P_{\text {inc }}$ without modification. $G_{0}$ and thermal parameters from [14] were incorporated into the natural garnet EoS determined here (Figure S2). Elastic relaxation is calculated within EoSFit7-P inc [41]. Note that QuiG pressures are always assumed to represent a minimum entrapment pressure, as inelastic processes always have the potential to relax the stress on an inclusion. To calculate QuiG pressures at a specified entrapment temperature, a temperature transect across the garnet was done using garnet-biotite thermometry on each EPMA point $[48,49]$. Uncertainty is estimated to be $25^{\circ} \mathrm{C}$ [50]. For this study, pressures are calculated at temperatures of $25{ }^{\circ} \mathrm{C}$ (for measurement) and $559{ }^{\circ} \mathrm{C}$ (for entrapment). Inclusions G3-4 and G3-5 had high fit uncertainties and interference on the $464 \mathrm{~cm}^{-1}$ band, and are likely not reliable or representative of metamorphic pressures.

Table 1. Unit cell parameters for garnet obtained from indexing SXD data in CrysAlis [39]. Pressure was measured using ruby fluorescence. Uncertainty on pressure is $<2.5 \%$ [51]. Unit cell parameters and volumes are obtained from SXD. Uncertainties on these are in parentheses.

\begin{tabular}{ccc}
\hline $\mathbf{P}(\mathbf{G P a})$ & $\mathbf{a}(\mathbf{\AA})$ & $\mathbf{V}\left(\mathbf{\AA}^{\mathbf{3}}\right)$ \\
\hline 0.33 & $11.5225(5)$ & $1529.82(12)$ \\
0.69 & $11.5182(5)$ & $1528.12(13)$ \\
1.63 & $11.5007(5)$ & $1521.13(11)$ \\
2.23 & $11.4903(5)$ & $1517.03(12)$ \\
2.72 & $11.4777(4)$ & $1512.03(10)$ \\
4.12 & $11.4478(4)$ & $1500.26(9)$ \\
4.56 & $11.4378(5)$ & $1496.34(12)$ \\
5.48 & $11.4206(3)$ & $1489.58(8)$ \\
7.36 & $11.3870(5)$ & $1476.49(11)$ \\
8.03 & $11.3744(3)$ & $1471.58(7)$ \\
9.47 & $11.3508(3)$ & $1462.46(6)$ \\
10.63 & $11.3337(3)$ & $1455.84(7)$ \\
\hline
\end{tabular}


Table 2. Bulk moduli $B_{0}$ and Volume $V_{0}$ for garnet end-members from (1) the most recent experimental data $[10,13,14],(2)$ internally consistent data [11], and (3) the garnet analyzed in this study and calculated assuming ideal mixing of the end-members weighted by the EPMA composition. Parameters in this study were obtained through fitting.

\begin{tabular}{cccc}
\hline Garnet & $\boldsymbol{B}_{\mathbf{0}}(\mathbf{G P a})$ & $\boldsymbol{B}_{\mathbf{0}}{ }^{\prime}$ & $\boldsymbol{V}_{\mathbf{0}}\left(\mathbf{\AA}^{\mathbf{3}} \mathbf{)}\right.$ \\
\hline Alm 1 [14] & $172.6(1.5)$ & $5.8(5)$ & $1530.48(10)$ \\
Sps 1 [13] & $171(4)$ & $5.3(8)$ & $1564.70(11)$ \\
Prp 1 [14] & $163.7(1.7)$ & $6.4(4)$ & $1506.15(16)$ \\
Grs 1 [10] & $166.6(2)$ & $4.96(7)$ & $1664.46(5)$ \\
\hline Alm 2 [11] & $185(3)$ & $4.2(3)$ & $1528.63(8)$ \\
Sps 2 [11] & $189(1)$ & 4.2 & $1563.64(8)$ \\
Prp 2 [11] & $171(2)$ & $4.4(2)$ & - \\
Grs 2 [11] & $175(1)$ & 4.4 & $1660.22(8)$ \\
\hline This Study & $172.0(57)$ & $6.2(16)$ & $1534.59(8)$ \\
V-ideal & $171.3(14)$ & $5.8(5)$ & $1536.52(11)$ \\
\hline
\end{tabular}

\section{Results}

This $\mathrm{Alm}_{74} \mathrm{Sps}_{13} \operatorname{Prp}_{10} \mathrm{Grs}_{3}$ garnet SXD data, obtained from crystals mounted within a DAC, were indexed in the known cubic metric from ambient pressure up to $10.6 \mathrm{GPa}$. No indication of a pressure induced phase transition was observed and the indexation clearly favored the I- centered cubic structure. The results of the single crystal indexing are shown in Figure 1 and given in Table 1.

A third order Birch Murnaghan EoS [40] was fitted to the experimental data in EoSFit7c [41] giving $V_{0}=1534.59(8) \AA^{3}, B_{0}=172.0(57) \mathrm{GPa}$, and $B_{0}^{\prime}=6.2(16)$. A Munaghan EoS [40] was also fitted to the experimental data giving $V_{0}=1534.60(8) \AA^{3}$, $B_{0}=167.5(81) \mathrm{GPa}$, and $B_{0}^{\prime}=5.2(15)$. However, to be consistent with published studies, the third-order Birch Murnaghan results are used in this analysis. The fitted volume is 0.13 percent smaller than the ideal mixing model volume of $1536.52 \AA^{3}$, which is calculated as weighted average of the published end-member data $[10,13,14]$. These are consistent within uncertainty. A plot of normalized stress versus Eulerian strain (F-f plot) was produced; however, high uncertainties obscure the results at the low pressure intervals precluding the use of this plot for determining reliable $B_{0}$ or $B_{0}^{\prime}$ values (Figure S1).

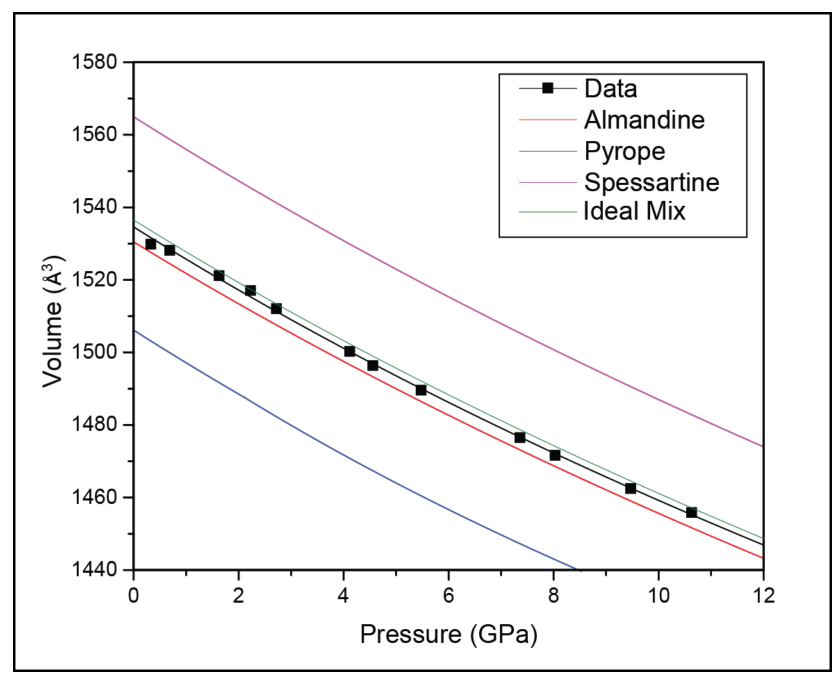

Figure 1. Pressure-volume data for the $\mathrm{Alm}_{74} \mathrm{Sps}_{13} \operatorname{Prp}_{10} \mathrm{Grs}_{3}$ garnet analyzed in this study with SXD plotted as black squares. Experimental errors are smaller than the data symbols. The black line is the third-order Birch-Murnaghan EoS fitted to the experimental data. EoS for end-member almandine [14], end-member pyrope [10], and end-member spessartine [13] are plotted for comparison. The green line is an EoS created using a weighted average of the $V_{0}, B_{0}$, and $B_{0}^{\prime}$ of the end-members. 
To demonstrate the possible effects of the EoS of garnet on the QuiG elastic geobarometer, QuiG pressures were calculated using the EoS determined in this study (Figure S2) and compared to pressures calculated using published EoS [10,14]. Garnet-biotite cation exchange thermometry [50] gave temperatures of garnet growth of $559{ }^{\circ} \mathrm{C}$ in the core and $596^{\circ} \mathrm{C}$ in the rim. The core temperature was used to calculate entrapment pressures because the inclusions analyzed were located in the garnet core. The highest entrapment pressure calculated using the EoS determined in this study was 0.930 GPa using the Grüneisen tensor approach (Table 3). Using an EoS for pure almandine, the highest entrapment pressure was also $0.930 \mathrm{GPa}$ (Table 3). Using the weighted average of the end-members, the highest entrapment pressure was $0.907 \mathrm{GPa}$ (Table 3). The Grüneisen tensor and hydrostatic approaches produced pressures within uncertainty (Figure 2). Note that the EoS for this garnet utilized thermal parameters for end-member almandine.

Table 3. Entrapment pressures calculated using different EoS and the inclusion pressures above. All pressures were calculated using $\mathrm{P}_{\text {stress}}$, except $\mathrm{P}-464$ which was calculating using $\mathrm{P}_{464}$ which assumes hydrostatic stress. This pressure was calculated with the EoS produced in this study. Incl. is the inclusion number. P-Alm, -Grs, -Prp, and -Sps are calculated using EoS for each endmember. P-Mix was calculated assuming ideal mixing. P-Tot was calculated using the EoS produced in this study. Pressures are in GPa and entrapment pressures are calculated at $559{ }^{\circ} \mathrm{C}$ using the full curved quartz EoS [46]. Uncertainty on entrapment pressures are $0.05 \mathrm{GPa}$ for P-464 and $0.24 \mathrm{GPa}$ for all other pressures.

\begin{tabular}{cccccccc}
\hline Incl. & P-Alm & P-Grs & P-Prp & P-Sps & P-Mix & P-Tot & P-464 \\
\hline G3-10 & 0.862 & 0.818 & 0.761 & 0.778 & 0.840 & 0.863 & 0.614 \\
G3-05 & 0.904 & 0.859 & 0.802 & 0.820 & 0.882 & 0.905 & 0.772 \\
G3-02 & 0.755 & 0.714 & 0.658 & 0.677 & 0.734 & 0.755 & 0.700 \\
G3-13 & 0.762 & 0.721 & 0.665 & 0.683 & 0.741 & 0.762 & 0.693 \\
G3-12 & 0.818 & 0.776 & 0.718 & 0.736 & 0.796 & 0.818 & 0.705 \\
G3-11 & 0.679 & 0.644 & 0.584 & 0.604 & 0.659 & 0.679 & 0.714 \\
G3-14 & 0.822 & 0.780 & 0.723 & 0.740 & 0.800 & 0.822 & 0.664 \\
G3-04 & 0.930 & 0.883 & 0.828 & 0.846 & 0.907 & 0.930 & 0.753 \\
G3-15 & 0.806 & 0.764 & 0.707 & 0.726 & 0.784 & 0.806 & 0.745 \\
\hline
\end{tabular}

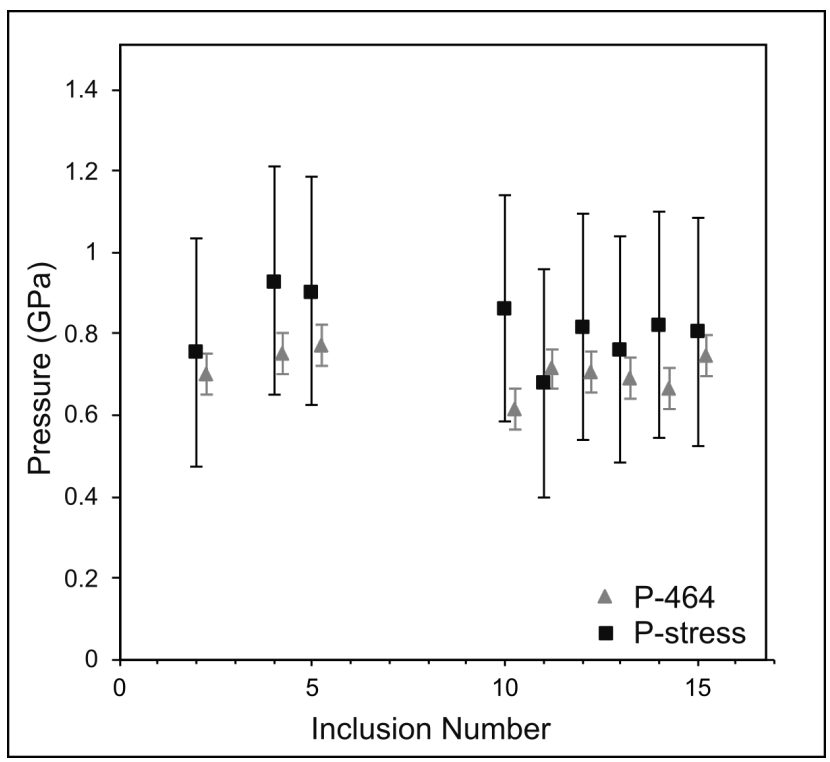

Figure 2. Comparison of P-stress calculated using Strainman [24] with EntraPT [44] and P-464 calculated using the hydrostatic mode shift calibration of [30]. Each pair of points represents a single inclusion with numbers corresponding to the Inlc. names above (Tables 3 and 4). The $x$-axis has been expanded for ease of comparison. 


\section{Discussion}

Although this garnet contains 26 percent $\mathrm{Mn}, \mathrm{Mg}$, and minor Ca on the X-site, it behaves within uncertainty equal to pure almandine during isothermal compression. Garnets in natural samples of crustal metapelites commonly have similar compositions to the garnet analyzed here, thus it is relevant for garnet geobarometry that the EoS is only minimally affected by the presence of these cations. We note that $\mathrm{Mg}$ and $\mathrm{Mn}$ content in almandine appear to have opposing effects on the $B_{0}$, with end-member pyrope and spessartine having $B_{0}=163.7 \mathrm{GPa}$ and $B_{0}=171.0 \mathrm{GPa}$, respectively, $[13,14]$ (Table 2). $V_{0}$ for spessartine and pyrope are nearly equally larger and smaller than almandine, respectively, (Figure 1). These opposing effects act to dampen the influences these cations have on the almandine solid solution EoS, causing the EoS of this natural garnet to overlap with pure end-member almandine within uncertainty. For this sample, the volume is within 0.26 percent and the bulk modulus is within 0.35 percent of end-member almandine [14]. The volume is within 0.13 percent of the calculated ideal mixing volume. Similar linear ideal mixing was observed for synthetic almandine-spessartine $[13,18]$ and almandine-pyrope solid solutions $[14,20]$. Our results do not display observed small positive deviations from ideal mixing that have been found in almandine-spessartine solid solutions [20]. Significant volume excess and microstrain are observed in pyrope-grossular solid solution garnets [9], but are not observed here. Due to its large size, the Ca cation is likely the primary cause of microstrain causing deviation from ideal-behavior, and since the garnet analyzed in this study has only three percent grossular it does not experience these effects. Differences in thermal expansion coefficients may not follow ideal-mixing and may affect the QuiG results [14]. This will be addressed in a future study. For this study, the room temperature volume determined using the third-order Birch-Murnaghan EoS is within uncertainty of the volume calculated assuming ideal mixing of end-members, suggesting that ideal mixing of these natural garnets, which is common practice in geobarometry, is a sufficient approximation for similar garnets.

We test QuiG simplifications by applying various EoS approaches and comparing the results. Pressures calculated using the EoS produced in this study, which directly describes compression of the garnet analyzed, returns ca. $0.02 \mathrm{GPa}$ higher pressures than those calculated using the weighted averages, and $0.001 \mathrm{GPa}$ higher than the pressures calculated using the EoS for pure almandine [14] (Table 4), all within uncertainty of the QuiG method (Figure 3). QuiG isomekes calculated for different end-members do not follow the same trend as the unit cell volumes or the bulk moduli of the garnet end-members (Figures 1 and 3). Although spessartine and pyrope have $V_{0}$ values that border the intermediate value of almandine, the isomekes for spessartine and pyrope nearly overlap and are both at lower pressures than almandine. Thermal expansion, inclusion relaxation, and shear moduli are additional variables in QuiG modeling that affect the isomekes, and further work is needed in these areas. Note that spessartine has the least well constrained EoS of the end-members, and, unlike almandine, pyrope, and grossular, there is not a widely used EoS for spessartine established for use with QuiG. Better constraints on the elastic parameters for this end-member are needed to enhance the robustness of QuiG pressure calculations, but the effect is likely small, as spessartine is rarely a significant component in pelitic garnets. According to the analysis here, the choice of EoS, whether from pure almandine or ideal mixing, does not significantly affect the final pressures. 


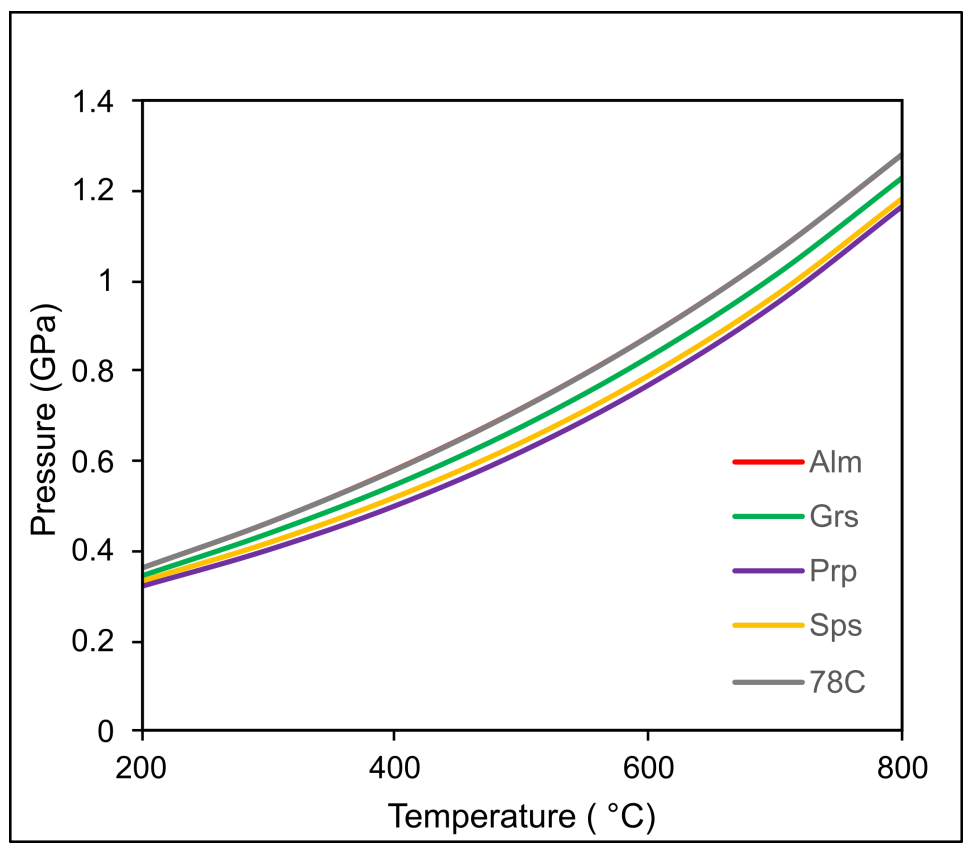

Figure 3. QuiG entrapment isomekes for the inclusion G3-15 ( $\left.\mathrm{P}_{\text {inc }}=0.126 \mathrm{GPa}\right)$ calculated using various equations of state $[10,13,14]$. Note that almandine overlaps with the EoS for garnet $78{ }^{\circ} \mathrm{C}$.

Table 4. Raman and strain data. Incl. is the inclusion number, 207 is the measured position of the 207 band, 464 is the position of the 464 band, $\mathrm{d}$ is the difference between the measured and standard positions, e are strains calculated in Strainman [24], $\mathrm{P}_{207}$ is the inclusion pressure calculated using the hydrostatic shift of 207 [30]. $\mathrm{P}_{464}$ is the inclusion pressure calculated using the hydrostatic shift of 464 [30], $\mathrm{P}_{\text {stress }}$ is the inclusion pressure calculated using the strains [44]. The uncertainties of $\mathrm{P}_{464}$ and $\mathrm{P}_{\text {stress }}$ are $0.05 \mathrm{Gpa}$ [30] and $0.3 \mathrm{GPa}$, respectively.

\begin{tabular}{|c|c|c|c|c|c|c|c|c|c|c|}
\hline Incl. & $\begin{array}{c}207 \\
\left(\mathrm{~cm}^{-1}\right)\end{array}$ & $\begin{array}{c}464 \\
\left(\mathrm{~cm}^{-1}\right)\end{array}$ & $\underset{\left(\mathrm{cm}^{-1}\right)}{\mathrm{d}_{207}}$ & $\begin{array}{c}\mathrm{d}_{464} \\
\left(\mathrm{~cm}^{-1}\right)\end{array}$ & e1 & $\mathrm{e} 1+\mathrm{e} 2$ & e3 & $\begin{array}{c}\mathbf{P}_{207} \\
(\mathrm{GPa})\end{array}$ & $\begin{array}{l}P_{464} \\
(\mathrm{GPa})\end{array}$ & $\begin{array}{r}P_{\text {stress }} \\
(\mathrm{GPa})\end{array}$ \\
\hline G3-10 & 209.14 & 465.03 & 2.47 & -0.10 & 0.0065 & -0.0129 & 0.00668 & 0.081 & -0.011 & 0.164 \\
\hline G3-05 & 210.33 & 466.05 & 3.65 & 0.92 & 0.0045 & -0.0090 & 0.00285 & 0.122 & 0.102 & 0.192 \\
\hline G3-02 & 208.43 & 465.61 & 1.76 & 0.48 & 0.0020 & -0.0040 & 0.00114 & 0.057 & 0.053 & 0.091 \\
\hline G3-13 & 208.51 & 465.57 & 1.84 & 0.44 & 0.0024 & -0.0047 & 0.00160 & 0.060 & 0.049 & 0.096 \\
\hline G3-12 & 209.12 & 465.64 & 2.45 & 0.51 & 0.0035 & -0.0070 & 0.00259 & 0.080 & 0.057 & 0.134 \\
\hline G3-11 & 210.09 & 465.69 & 3.41 & 0.56 & 0.0057 & -0.0113 & 0.00467 & 0.114 & 0.062 & 0.038 \\
\hline G3-14 & 208.98 & 465.37 & 2.31 & 0.24 & 0.0045 & -0.0089 & 0.00405 & 0.076 & 0.027 & 0.137 \\
\hline G3-04 & 210.23 & 466.23 & 3.55 & 0.81 & 0.0066 & -0.0132 & 0.00588 & 0.118 & 0.090 & 0.209 \\
\hline G3-15 & 209.22 & 465.88 & 2.55 & 0.76 & 0.0026 & -0.0051 & 0.00122 & 0.084 & 0.084 & 0.126 \\
\hline
\end{tabular}

Comparing the hydrostatic and Grüneisen tensor approaches reveals no measurable difference between the two, but demonstrates the challenge of applying the Grüneisen tensor approach to Barrovian metamorphic rocks. For the hydrostatic approach, $\mathrm{P}_{207}$ and $\mathrm{P}_{464}$ are generally consistent (Table 4), considering the high uncertainty on the $207 \mathrm{~cm}^{-1}$ band, suggesting that the 207 band was likely not influenced significantly by interference from the host garnet, which has been observed on $207 \mathrm{~cm}^{-1}$ band in some garnet varieties [52]. We compare the $464 \mathrm{~cm}^{-1}$ mode (the most intense in the quartz Raman spectra) pressures to the Grüneisen tensor approach pressures because the $464 \mathrm{~cm}^{-1}$ band is considered to be the most reliable mode. The hydrostatic $464 \mathrm{~cm}^{-1}$ method reports apparent lower pressures than the Grüneisen tensor approach except for inclusion G3-11, but all are within uncertainty (Figure 2). Uncertainties reported by EntraPT [44] for the Grüneisen tensor entrapment pressures calculated in this study are $0.3 \mathrm{GPa}$ when calculated using two modes, compared to $0.05 \mathrm{GPa}$ for the hydrostatic method. Notably, an uncertainty of $0.3 \mathrm{GPa}$ is too high for extracting meaningful geologic pressures in common geologic settings, as 
Barrovian metamorphic pressures are typically between 0.5 to $1.0 \mathrm{GPa}$, demonstrating the challenges of applying this method to low-to-intermediate pressure metamorphic rocks.

\section{Conclusions}

An EoS fitted to experimental data for this natural garnet of composition $\mathrm{Alm}_{74} \mathrm{Sps}_{13} \operatorname{Prp}_{10} \mathrm{Grs}_{3}$ follows ideal solid solution mixing. The determined EoS and an EoS produced using an ideal solid solution mix of $V_{0}, B_{0}$, and $B_{0}^{\prime}$ of the garnet compositional end-members are within uncertainty (Figure 1). The results of this study suggest that natural garnets comprised of 70-80 percent almandine likely have sufficiently low proportions of $\mathrm{Mn}, \mathrm{Mg}$, and, of particular importance, Ca to be assumed to follow ideal solid solution mixing behavior, justifying these practices in geobarometry. This may be restricted to almandine garnets with nearly equal proportions of $\mathrm{Mn}$ and $\mathrm{Mg}$, which also may be able to be approximated as compressing similarly to end-member almandine. These simplifications are supported by consistency in QuiG isomekes (Figure 3). According to the QuiG analysis, entrapment pressures obtained using ideal mixing of end-member EoS and the pure almandine EoS overlap within uncertainty with the pressures obtained using the EoS that directly describes compression of this garnet. At similar P-T conditions and garnet compositions, any of the approaches reproduce pressures of inclusion entrapment. This observation constitutes one more line of evidence supporting the use of QuiG for metamorphic pressure determination, and suggests that a generic EoS for similar garnets, such as the EoS produced here, should produce adequate pressures of entrapment using QuiG.

Supplementary Materials: The following are available online at https:/ /www.mdpi.com/article/ 10.3390/min11050458/s1, Figure S1: F-f plot; Figure S2: EoS file; Table S1: Raman standards table; Table S2: QuiG data table.

Author Contributions: Conceptualization, S.R.M. and E.S.; software, S.C.; resources, A.S., T.D.H.; data curation, V.P., S.C., A.S., T.D.H., A.G.S.; writing—original draft preparation, S.R.M.; writingreview and editing, S.R.M., E.S., O.T. and M.L.W.; supervision, E.S., O.T. and M.L.W.; funding acquisition, M.L.W. All authors have read and agreed to the published version of the manuscript.

Funding: The publication fees for this article were supported by the UNLV University Libraries Open Article Fund.

Data Availability Statement: The data presented in this study are openly available in Creative Commons Attribution at https:// doi.org/10.3390/min1010001, accessed on 16 March 2021.

Acknowledgments: We thank the Explosives Dynamic Material Properties research program at LLNL for funding support of this project. We thank Eric D. Kelly for providing rock samples. Part of this work was performed under the auspices of the U.S. Department of Energy by Lawrence Livermore National Security, LLC under Contract DE-AC52-07NA27344. Part of this work was performed at GeoSoilEnviroCARS (The University of Chicago, Sector 13), Advanced Photon Source (APS), Argonne National Laboratory. GeoSoilEnviroCARS is supported by the National Science Foundation-Earth Sciences (EAR-1634415) and Department of Energy-GeoSciences (DE-FG0294ER14466). This research used resources of the Advanced Photon Source, a U.S. Department of Energy (DOE) Office of Science User Facility operated for the DOE Office of Science by Argonne National Laboratory under Contract No. DE-AC02-06CH11357.

Conflicts of Interest: The authors declare no conflict of interest.

\section{References}

1. Geller, S. Crystal chemistry of the garnets. In Zeitschrift fur Kristallographie-New Crystal Structures; De Gruyter: Berlin, Germany, 1967. [CrossRef]

2. Huang, S.; Chen, J. Equation of state of pyrope-almandine solid solution measured using a diamond anvil cell and in situ synchrotron X-ray diffraction. Phys. Earth Planet. Inter. 2014, 228, 88-91. [CrossRef]

3. Wijbrans, C.H.; Rohrbach, A.; Klemme, S. An experimental investigation of the stability of majoritic garnet in the Earth's mantle and an improved majorite geobarometer. Contrib. Mineral. Petrol. 2016, 50, 171. [CrossRef] 
4. Bosenick, A.; Dove, M.T.; Heine, V.; Geiger, C.A. Scaling of thermodynamic mixing properties in garnet solid solutions. Phys. Chem. Miner. 2001, 28, 177-187. [CrossRef]

5. Ganguly, J.; Saxena, S.K. Mixing properties of aluminosilicate garnets: Constraints from natural and experimental data, and applications to geothermo- barometry: Clarifications. Am. Mineral. 1985, 70, 1320.

6. Ganguly, J.; Cheng, W.; Tirone, M. Thermodynamics of aluminosilicate garnet solid solution: New experimental data, an optimized model, and thermometric applications. Contrib. Mineral. Petrol. 1996, 137-151, 126. [CrossRef]

7. Bosenick, A.; Geiger, C.A.; Cemič, L. Heat capacity measurements of synthetic pyrope-grossular garnets between 320 and $1000 \mathrm{~K}$ by differential scanning calorimetry. Geochim. Cosmochim. Acta 1996, 17, 3215-3220. [CrossRef]

8. Du, W.; Clark, S.M.; Walker, D. Excess mixing volume, microstrain, and stability of pyrope-grossular garnets. Am. Mineral. 2016, 60, 3215-3227. [CrossRef]

9. Du, W.; Clark, S.M.; Walker, D. Thermo-compression of pyrope-grossular garnet solid solutions: Non-linear compositional dependence. Am. Mineral. 2015, 100, 215-222. [CrossRef]

10. Milani, S.; Angel, R.J.; Scandolo, L.; Mazzucchelli, M.L.; Ballaran, T.B.; Klemme, S.; Domeneghetti, M.C.; Miletich, R.; Scheidl, K.S.; Derzsi, M.; et al. Thermo-elastic behavior of grossular garnet at high pressures and temperatures. Am. Mineral. 2017, 102, 851-859. [CrossRef]

11. Zhang, L.; Ahsbahs, H.; Kutoglu, A.; Geiger, C.A. Single-crystal hydrostatic compression of synthetic pyrope, almandine, spessartine, grossular and andradite garnets at high pressures. Phys. Chem. Miner. 1999, 27, 52-58. [CrossRef]

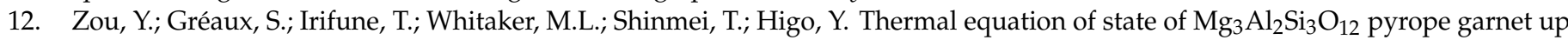
to $19 \mathrm{GPa}$ and 1700 K. Phys. Chem. Miner. 2012, 39, 589-598. [CrossRef]

13. Gréaux, S.; Yamada, A. P-V-T equation of state of $\mathrm{Mn}_{3} \mathrm{Al}_{2} \mathrm{Si}_{3} \mathrm{O}_{12}$ spessartine garnet. Phys. Chem. Miner. 2014, 41, 141-149. [CrossRef]

14. Milani, S.; Nestola, F.; Alvaro, M.; Pasqual, D.; Mazzucchelli, M.L.; Domeneghetti, M.C.; Geiger, C.A. Diamond-garnet geobarometry: The role of garnet compressibility and expansivity. Lithos 2015, 227, 140-147. [CrossRef]

15. Guiraud, M.; Powell, R. How well known are the thermodynamics of Fe-Mg-Ca garnet? Evidence from experimentally determined exchange equilibria. J. Metamorph. Geol. 1996, 14, 75-84. [CrossRef]

16. Ungaretti, L.; Leona, M.; Merli, M.; Oberti, R. Non-ideal solid-solution in garnet: Crystal-structure evidence and modelling. Euro. J. Mineral. 1995, 7, 1299-1312. [CrossRef]

17. Fan, D.W.; Zhou, W.G.; Liu, C.Q.; Liu, Y.G.; Wan, F.; Xing, Y.S.; Liu, J.; Bai, L.G.; Xie, H.S. The thermal equation of state of (Fe 0.86 $\mathrm{Mg} 0.07 \mathrm{Mn} 0.07$ ) $3 \mathrm{Al}_{2} \mathrm{Si}_{3} \mathrm{O}_{12}$ almandine. Mineral. Mag. 2009, 73, 95-102. [CrossRef]

18. Fan, D.; Xu, J.; Ma, M.; Liu, J.; Xie, H. P-V-T equation of state of spessartine-almandine solid solution measured using a diamond anvil cell and in situ synchrotron X-ray diffraction. Phys. Chem. Miner. 2015, 42, 63-72. [CrossRef]

19. Sobolev, N.V.; Schertl, H.P.; Burchard, M.; Shatsky, V.S. An unusual pyrope-grossular garnet and its paragenesis from diamondiferous carbonate-silicate rocks of the Kokchetav massif, Kazakhstan. In Doklady Earth Sciences; Pleiades Publishing, Ltd.: New York, NY, USA, 2001.

20. Geiger, C.A.; Feenstra, A. Molar volumes of mixing of almandine-pyrope and almandine-spessartine garnets and the crystal chemistry and thermodynamic-mixing properties of the aluminosilicate garnets. Am. Mineral. 1997, 82, 571-581. [CrossRef]

21. Geiger, C.A.; Newton, R.C.; Kleppa, O.J. Enthalpy of mixing of synthetic almandine-grossular and almandine-pyrope garnets from high-temperature solution calorimetry. Geochim. Cosmochim. Acta 1987, 51, 1755-1763. [CrossRef]

22. Geiger, C.A. Volumes of mixing in aluminosilicate garnets: Solid solution and strain behavior. Am. Mineral. 2000, 85, 893-897. [CrossRef]

23. Thomas, J.B.; Spear, F.S. Experimental study of quartz inclusions in garnet at pressures up to 3.0 GPa: Evaluating validity of the quartz-in-garnet inclusion elastic thermobarometer. Contrib. Mineral. Petrol. 2018, 173, 1-14. [CrossRef]

24. Angel, R.J.; Murri, M.; Mihailova, B.; Alvaro, M. Stress, strain and Raman shifts. In Zeitschrift fur Kristallographie-Crystalline Materials; De Gruyter: Berlin, Germany, 2019. [CrossRef]

25. Angel, R.J.; Mazzucchelli, M.L.; Alvaro, M.; Nestola, F. EosFit-Pinc: A simple GUI for host-inclusion elastic thermobarometry. Am. Mineral. 2017, 102, 1957-1960. [CrossRef]

26. Spear, F.S.; Thomas, J.B.; Hallett, B.W. Overstepping the garnet isograd: A comparison of QuiG barometry and thermodynamic modeling. Contrib. Mineral. Petrol. 2014, 168, 1059. [CrossRef]

27. Kohn, M.J. "Thermoba-Raman-try": Calibration of spectroscopic barometers and thermometers for mineral inclusions. Earth Planet. Sci. Lett. 2014, 388, 187-196. [CrossRef]

28. Wolfe, O.M.; Spear, F.S. Determining the amount of overstepping required to nucleate garnet during Barrovian regional metamorphism, Connecticut Valley Synclinorium. J. Metamorph. Geol. 2018, 36, 79-94. [CrossRef]

29. Zuza, A.V.; Levy, D.A.; Mulligan, S. Geologic field evidence for non-lithostatic overpressure recorded in the North American Cordillera hinterland, northeast Nevada. Geosci. Front. 2020. [CrossRef]

30. Schmidt, C.; Ziemann, M.A. In-situ Raman spectroscopy of quartz: A pressure sensor for hydrothermal diamond-anvil cell experiments at elevated temperatures. Am. Mineral. 2000, 85, 1725-1734. [CrossRef]

31. Bonazzi, M.; Tumiati, S.; Thomas, J.B.; Angel, R.J.; Alvaro, M. Assessment of the reliability of elastic geobarometry with quartz inclusions. Lithos 2019, 350-351, 105201. [CrossRef] 
32. Moulas, E.; Kostopoulos, D.; Podladchikov, Y.; Chatzitheodoridis, E.; Schenker, F.L.; Zingerman, K.M.; Pomonis, P.; Tajčmanová, L. Calculating pressure with elastic geobarometry: A comparison of different elastic solutions with application to a calc-silicate gneiss from the Rhodope Metamorphic Province. Lithos 2020, 378-379, 105803. [CrossRef]

33. Kelly, E.D.; Hoisch, T.D.; Wells, M.L.; Vervoort, J.D.; Beyene, M.A. An Early Cretaceous garnet pressure-temperature path recording synconvergent burial and exhumation from the hinterland of the Sevier orogenic belt, Albion Mountains, Idaho. Contrib. Mineral. Petrol. 2015, 20, 170. [CrossRef]

34. Kantor, I.; Prakapenka, V.; Kantor, A.; Dera, P.; Kurnosov, A.; Sinogeikin, S.; Dubrovinskaia, N.; Dubrovinsky, L. BX90: A new diamond anvil cell design for X-ray diffraction and optical measurements. Rev. Sci. Instrum. 2012, 83, 125102. [CrossRef]

35. Klotz, S.; Chervin, J.C.; Munsch, P.; Le Marchand, G. Hydrostatic limits of 11 pressure transmitting media. J. Phys. D Appl. Phys. 2009, 42, 075413. [CrossRef]

36. Syassen, K. Ruby under pressure. High Press. Res. 2008, 28, 75-126. [CrossRef]

37. Matsui, M. High temperature and high pressure equation of state of gold. J. Phys. 2010, 215, 012197. [CrossRef]

38. Prakapenka, V.B.; Kubo, A.; Kuznetsov, A.; Laskin, A.; Shkurikhin, O.; Dera, P.; Rivers, M.L.; Sutton, S.R. Advanced flat top laser heating system for high pressure research at GSECARS: Application to the melting behavior of germanium. High Press. Res. 2008, 28, 225-235. [CrossRef]

39. Agilent. CrysAlisPro Data Collection and Processing Software for Agilent X-ray Diffractometers; Technologies UK Ltd.: Oxford, UK, 2014.

40. Birch, F. Finite strain isotherm and velocities for single-crystal and polycrystalline $\mathrm{NaCl}$ at high pressures and $300^{\circ} \mathrm{K}$. J. Geophys. Res. 1978, 83, 1257-1268. [CrossRef]

41. Angel, R.J.; Gonzalez-Platas, J.; Alvaro, M. EosFit7c and a Fortran module (library) for equation of state calculations. Z. Krist. 2014, 229, 405-419. [CrossRef]

42. Isaak, D.G.; Anderson, O.L.; Oda, H. High-temperature thermal expansion and elasticity of calcium-rich garnets. Phys. Chem. Miner. 1992, 19, 106-120. [CrossRef]

43. Wojdyr, M. Fityk: A general-purpose peak fitting program. J. Appl. Crystallogr. 2010, 43, 1120-1128. [CrossRef]

44. Mazzucchelli, M.L.; Angel, R.J.; Alvaro, M. EntraPT: An online platform for elastic geothermobarometry. Am. Mineral. 2020, 106, 830-837. [CrossRef]

45. Johnson, T.A.; Cottle, J.M.; Larson, K.P. Delineation of multiple metamorphic events in the Himalayan Kathmandu Complex, central Nepal. J. Metamorph. Geol. 2020, 39, 443-472. [CrossRef]

46. Angel, R.J.; Alvaro, M.; Miletich, R.; Nestola, F. A simple and generalised P-T-V EoS for continuous phase transitions, implemented in EosFit and applied to quartz. Contrib. Mineral. Petrol. 2017, 29, 172. [CrossRef]

47. Holland, T.; Powell, R. An enlarged and updated internally consistent thermodynamic dataset with uncertainties and correlations: The system $\mathrm{K}_{2} \mathrm{O}-\mathrm{Na}_{2} \mathrm{O}-\mathrm{CaO}-\mathrm{MgO}-\mathrm{MnO}-\mathrm{FeO}-\mathrm{Fe}_{2} \mathrm{O}_{3}-\mathrm{Al}_{2} \mathrm{O}_{3}-\mathrm{TiO}_{2}-\mathrm{SiO}_{2}-\mathrm{C}-\mathrm{H}_{2}-\mathrm{O}_{2}$. J. Metamorph. Geol. 1990, 8, 89-124. [CrossRef]

48. Hodges, K.V.; Spear, F.S. Geothermometry, geobarometry and the $\mathrm{Al}_{2} \mathrm{SiO}_{5}$ triple point at Mt. Moosilauke, New Hampshire. Am. Mineral. 1982, 67, 1118-1134.

49. Hoisch, T.D. Equilibria within the mineral assemblage quartz + muscovite + biotite + garnet + plagioclase, and implications for the mixing properties of octahedrally-coordinated cations in muscovite and biotite. Contrib. Mineral. Petrol. 1991, $108,43-54$. [CrossRef]

50. Holdaway, M.J. Application of new experimental and garnet Margules data to the garnet-biotite geothermometer. Am. Mineral. 2000, 85, 881-892. [CrossRef]

51. Shen, G.; Wang, Y.; Dewaele, A.; Wu, C.; Fratanduono, D.E.; Eggert, J.; Klotz, S.; Dziubek, K.F.; Loubeyre, P.; Fat'yanov, O.V.; et al. Toward an international practical pressure scale: A proposal for an IPPS ruby gauge (IPPS-Ruby2020). High Press. Res. 2020, 40, 299-314. [CrossRef]

52. Enami, M. Influence of garnet hosts on the raman spectra of quartz inclusions. J. Mineral. Petrol. Sci. 2012, 107, 173-180. [CrossRef] 